\title{
Transferrin polymorphism of red deer in France: evidence for spatial genetic microstructure of an autochthonous herd
}

\author{
A Schreiber ${ }^{1}$, F Klein ${ }^{2}$, G Lang ${ }^{3}$ \\ 1 Zoologisches Institut der Universität Heidelberg, \\ Im Neuenheimer Feld 230, 69120 Heidelberg, Germany; \\ 2 Office National de la Chasse, Station Sangliers-Cervidés, \\ Au Bord du Rhin, 67150 Gerstheim; \\ 3 Groupement CERF, 26a, rue Principale, 67240 Gries, France
}

(Received 26 April 1993; accepted 3 January 1994)

Summary - Population genetics of the transferrin polymorphism is analyzed in 549 red deer from mainland France (Vosges, Arc-en-Barrois, Chambord, Allier), and Corsica. Evidence is provided for significant deficiency of heterozygotes, and for allele frequency differentiation between adjacent matrilocal demes of philopatric hinds and offspring in red deer from Vosges du Nord. In this autochthonous population, the effective population size (recognizing effects of social and age structure on genetic drift) amounts to 209 per 800 deer. Mean dispersal distances of $2.55 \mathrm{~km}$ in females and $19 \mathrm{~km}$ in males lead to neighborhood areas of randomly mixing deer which argue against isolation by distance within the study population. Among mainland red deer in France, the fenced herd at Chambord is distinguished by its elevated heterozygosity.

transferrin polymorphism / Cervus elaphus / population size / matrilocal deme

Résumé - Le polymorphisme de la transferrine chez le cerf élaphe de France : un argument en faveur d'une structuration génétique microspatiale d'une population indigène. La variabilité électrophorétique de la transferrine a été examinée chez 549 cerfs (Cervus elaphus $L$ ) originaires de 6 populations françaises (Vosges, Arc-en-Barrois, Chambord, Allier et Corse). Les analyses sont limitées à 2 allèles et concernent des animaux tirés ou attrapés pendant les saisons de chasse 1988/90, 1990/91 et 1991/92. Une nette déficience en hétérozygotes au locus de la transferrine a été mise en évidence pour la population indigène de cerfs des Vosges du Nord, dont l'effectif efficace est au moins de 209 individus. On constate également une différence significative entre les fréquences alléliques de groupes matriarcaux philopatriques, composés de biches et de faons, occupant des territoires contigus dans la réserve nationale de chasse de la Petite-Pierre (non close et faisant partie intégrante de la population des Vosges du Nord). Le polymorphisme de la transferrine révèle un développement en microstructures génétiques entre populations 
locales alors qu'il n'existe aucune barrière géographique. Cette microstructure a pu être confirmée grâce à la connaissance d'un certain nombre de paramètres sociologiques, d'un suivi régulier des animaux, d'une connaissance de la dispersion des mâles et des femelles ainsi qu'à la bonne connaissance du domaine vital. Les nombreuses données acquises tout au long du suivi des animaux de la réserve nationale de la Petite-Pierre nous ont permis d'estimer une valeur plancher pour l'effectif génétique $\left(N_{e}\right)$ et de calculer un "effectif spatial efficace» dépendant de l'aire de dispersion du cerf élaphe. La population des cerfs du parc de Chambord se distingue par des valeurs élevées d'hétérozygotie.

polymorphisme de la transferrine / Cervus elaphus / taille de population / groupe matriarcal philopatrique

\section{INTRODUCTION}

Red deer (Cervus elaphus) is the largest mammalian herbivore in most European forests. In Central Europe, the species is now confined to isolated habitats, and management of genetic variability of deer populations has aroused some interest (Lang, 1987; Herzog, 1988; Hartl et al, 1990, 1991; Hergoz et al, 1991; Klein et al, 1992). The Vosges mountains in France contain one of the largest autochthonous populations of the subspecies Ce hippelaphus remaining in continental western Europe outside the Alps (numbering some 7000 individuals after a recent reduction from 10000 animals) which has not been affected by the introduction of foreign stock for trophy hunting. Therefore, Vosgian deer represent suitable objects to study natural genetic differentiation of the species. Several investigations demonstrated small-scale spatial subdivision within populations of white-tailed deer (Odocoileus virginianus), even across distances of just a few miles (Manlove et al, 1976; Chesser et al, 1982); Smith et al, 1984); Nelson and Mech, 1987; Scribner, 1993). In other cervid species, electrophoretic differentiation has been observed for subspecies or geographic populations (Dratch and Pemberton, 1992). This differentiation can complicate population concepts for evolutionary studies and may be relevant when selecting founder specimens for subsequent reintroduction into game-free territories, a common practice also for red deer in France and elsewhere. However, the considerable knowledge on the population fine structure of Odocoileus is of limited use for red deer management, since the white-tailed deer is adapted to colonize habitats at early stages of vegetation succession, and has been classified as an opportunistic r-strategist with flexible demography (Harrington, 1985), similar to European roe deer (Hartl and Reimoser, 1988; Kurt, 1991). In constrast, the reproductive potential of red deer is lower, its ability to colonize unstable habitats more limited, and its lifestyle points to the pattern of a less flexible k-strategist (Kurt, 1991). Population genetics of red deer is insufficiently known to be able to recognize the influence of social structures, dispersal patterns, and mating systems on the genetically effective population size. We are unaware of any published estimates of effective population sizes of red deer, which would be an indicator of the rate of loss of genetic variation by drift, and whose calculation provides a basic contribution for managing relict herds.

Previously, we presented evidence of heterozygote deficiency at the transferrin locus in Vosgian red deer (Schreiber et al, 1992) but could only speculate about the 
cause for this phenomenon. Based on a larger sample size from Vosges du Nord and from another 4 regions of France, and on the analysis of a long-term study of the social structure of Vosgian red deer (F Klein, unpublished data), this article shows that social organization in matrilocal groups consisting of philopatric hinds, calves and yearlings from both sexes exerts an influence on $T f$ allele frequency within a free-ranging population of autochthonous red deer. We present our analysis of demographic and dispersal parameters of Vosgian deer, based on electrophoretic analysis of the biallelic $T f$ gene, behavior studies and investigations into dispersal distances, as a step towards the estimation of red deer's effective population size $\left(N_{\mathrm{e}}\right)$, and of the neighborhood area inhabited by randomly mixing groups unaffected by distance isolation.

Transferrin $(T f)$ is an iron-binding serum protein of the $\beta$-globulin fraction of which 2 alleles have been found in Scottish populations of red deer by McDougall and Lowe (1968) and Pemberton et al (1988), although McDougall and Lowe (1968) described one additional very rare variant. Bergmann (1976), Mushövel (1986), Herzog (1988) and Herzog et al (1991) encountered $3 T f$ alleles in several populations from Germany, 2 of which were common, as did Gyllensten et al (1980, 1983) in Sweden. Different names have been chosen by various investigators to describe their electrophoretic patterns and the plausible assumption that at least the 2 main alleles are identical remains to be confirmed. Herzog (1988) analyzed segregation of his 2 common $T f$ types in a known pedigree of 15 families and confirmed their inheritance as genetic alleles. Pemberton et al (1988) compared the fitness of carriers of $T f$ genotypes in red deer from Rhum (Scotland), demonstrating an increased probability of heterozygote deer to survive as juveniles.

\section{MATERIALS AND METHODS}

\section{Study populations}

During the hunting seasons of 1989/1990, 1990/1991 and 1991/1992, plasma samples from 549 free-ranging red deer were obtained from 6 herds in 4 regions of France (fig 1). In addition, some 50 samples from captive red deer were used for reference. These included 14 complete families (mothers with one calf sired by one of 2 stags) from the Institut National de Recherche Agronomique. In the Vosges, some 500 deer survived periods of intense hunting in the Donon area, where the mountain chain has been recolonized (Lang, 1987; Jung, 1990). Approximately 980 deer have been separated in the Vosges du Nord (Bas-Rhin) from the bulk of the herd by the fenced Paris-Strasbourg motorway since 1976 (ie 2 generations of red deer). The 320 deer living in the Réserve Nationale de la Chasse de la Petite Pierre (2600 ha) are part of the larger population in Vosges du Nord whose movements are not restricted by obvious ecological or land-use boundaries. Until the end of October, samples were obtained from deer shot from hides or by stalking ( $i e$ within their native ranges). Between November and February, collective drive hunts using dogs and human drivers chased deer completely from larger areas (60-100 ha).

Nine Vosgian deer (2 stags, 4 hinds and 3 juveniles) were used to found a herd at Saint Augustin (Allier). The population at Arc-en-Barrois (Haute-Marne) comprises 


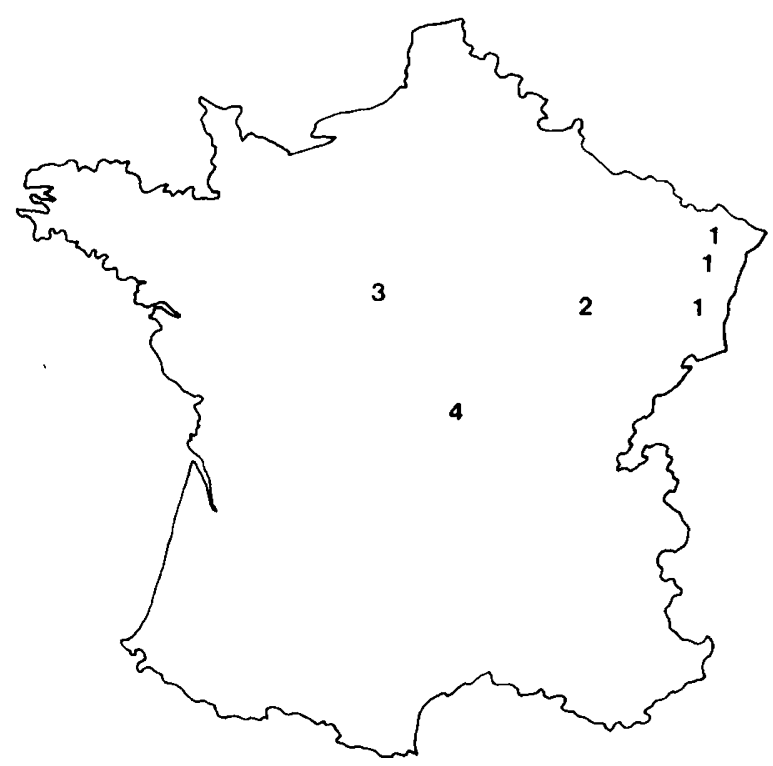

Fig 1. Location of sampled red-deer populations in mainland France.

600-800 autochthonous deer (sex ratio: 1 stag per 1.2 hinds). At Chambord (Loiret-Cher), 12-15 deer per 100 ha occupy a fenced forest of 5000 ha which served as hunting ground of the French aristocracy for centuries. While lacking detailed information, we can safely assume that deer from other areas have been repeatedly introduced for hunting purposes. Tyrrhenian red deer represent a distinct subspecies (Ce corsicanus) endemic to Corsica (where it was hunted to extinction) and Sardinia. Our samples originate from the deer used to reintroduce the subspecies into Corsica. Twelve Taiwan sika deer (Cervus nippon taiwanus) were bloodsampled at Whipsnade Wild Animal Park (UK).

\section{Sample acquisition}

Sterile blood samples from 109 live-captured deer (net traps) were collected from the jugular vein. Another 440 blood samples (ACD with sodium azide) from freeranging animals were acquired with the help of numerous hunters. These samples, collected from opened blood vessels of shot deer, were included in the present study if their $T f$ patterns proved stable and identical to those found in sterile plasma. For each hunted specimen, a questionnaire was received containing information about age, sex, the exact locality and several biometric traits of the individual. Noting the possibility of spatial shifts in frequency over very short geographic distances (see Results), only whose 469 individuals with known biological data were included.

Electrophoresis was carried out in polyacrylamide gels as described previously (Schreiber et al, 1992). In addition, resolution of the alleles was reproduced by isoelectric focusing according to Schreiber (1991). 


\section{Delimitation of matrilocal groups}

Within the Réserve Nationale de la Chasse de la Petite Pierre (2600 ha), 62 stags and 86 hinds were captured, tagged with necklaces and their movements followed by individual-centered observations or telemetry. Social grouping of deer in matrilocal groups became apparent over a study period of $10 \mathrm{yr}$.

\section{Calculation of effective population size}

$N_{e}$ was estimated according to the formulae described by Nunney (1991), using the following empirically based demographic traits of red deer from Vosges du Nord: sex ratio of reproductive animals: 0.346 stags for 0.654 hinds; average fecundity (male $>4 \mathrm{yr}$, females $>2 \mathrm{yr}$ ): 1.72 offspring; mean generation time: $6.35 \mathrm{yr}(6.36 \mathrm{yr}$ in hinds, and $6.34 \mathrm{yr}$ in stags); annual net increase per hind: 0.66 (spring population of females $>1 \mathrm{yr}$ ) or 0.908 (breeding hinds $>2 \mathrm{yr}$ ); annual variation in the number of calves per hind: $0-1$. In order to avoid overestimation of $N_{e}$ when the variance in demographic traits was not available from empirical data, we adopted the maximum variance emerging from the variation which is well known in all cases. Only 800 deer were taken as numerical population in Vosges du Nord (against 980 counted in the last surveys) to avoid overestimation of $N_{e}$. No empirical data are available to quantify average polygyny of stags in the study population. Therefore, the finding by Pemberton et al (1992) of 0-14 offspring per stag and year in the Scottish population at Rhum has been included in our calculation. Considering the lower abundance of red deer in Vosgian forests, and certain differences in social behavior (including a much lower harem size), the adoption of this variation in reproductive success certainly is a safe assumption which does diminish $N_{e}$ more than reality. Based on 156 observations, the mean harem size in Vosges du Nord was 1.5 hinds per stag, with a variation of 1-7 (variance 0.9 ). The possible additional reduction of $N_{e}$ by subdivision of stocks into randomly mating subpopulations is linked to the one-way variance of dispersal distance of specimens, as stated in the following formula (Chepko-Sade and Shields, 1987):

$$
N_{e}=4 \pi \operatorname{var} d
$$

where var denotes the one-way variance of dispersal distances, and $d$ is the population density of deer.

\section{RESULTS}

The 3 common electrophoretic $T f$ patterns encountered in fresh sterile plasma are obviously determined by 2 alleles, $T f a$ and $T f b$ ( $T f a$ denoting the anodal variant). Densitometry confirmed that Coomassie-stained bands in heterozygous patterns contained approximately $50 \%$ of the protein of corresponding bands in homozygous patterns, as in a simple gene-dosage relationship. Segregation of $T f$ alleles was compatible with expectation in 14 families of captive-bred red deer (table I). In some samples collected by hunters and mailed to the laboratory, additional $T f$ patterns with decreasing electrophoretic mobility were encountered. We 
Table I. Segregation of electrophoretic $T f$ patterns in a pedigree population of captive red deer.

\begin{tabular}{lccc}
\hline Parental generation & \multicolumn{3}{c}{ Filial generation } \\
\cline { 2 - 4 } & TfAA & TfAB & TfBB \\
\hline $\operatorname{Tf} A A(\mathrm{~m}) \times T f B B(\mathrm{f})$ & - & 1 & - \\
$\operatorname{Tf} A A(\mathrm{~m}) \times T f A A(\mathrm{f})$ & 7 & - & - \\
$\operatorname{Tf} A A(\mathrm{~m}, \mathrm{f}) \times T f A B(\mathrm{~m}, \mathrm{f})$ & 3 & - & - \\
$\operatorname{Tf} A B(\mathrm{~m}) \times T f A B(\mathrm{f})$ & - & 2 & 1 \\
\hline
\end{tabular}

failed to find these patterns in sterile plasma collected from live-captured deer. Lacking reference sera for this allele, and noting that microbial contamination also led to aberrant lowering of electrophoretic mobility (although we had added sodium azide during the transport of samples), we neglected a possible third rare allele and confined our analysis to $T f a$ and $T f b$. A possible third allele would be too rare to influence the deviation from Hardy-Weinberg conditions discussed below. The genotype numbers, allele frequencies and tests of genetic equilibria of $T f$ polymorphism in deer from various origins in France are listed in table II.

Table II. Genotype numbers, allele frequencies and observed heterozygosity $(H)$ at the $T f$ locus of 469 red deer from France. For the Vosges mountains, the various localities are listed separately.

\begin{tabular}{lrrrrrrr}
\hline & $\mathrm{n}$ & TfAA & TfAB & TfBB & H & Tfa & Tfb \\
\hline Vosges & 126 & 101 & 9 & 16 & 0.071 & 0.837 & 0.163 \\
$\quad$ Vosges du Nord & 101 & 78 & 9 & 14 & 0.090 & 0.817 & 0.183 \\
$\quad$ Reserve of La Petite Pierre & 78 & 60 & 7 & 11 & 0.090 & 0.814 & 0.186 \\
$\quad$ Bouxwiller & 50 & 41 & 5 & 4 & 0.100 & 0.870 & 0.130 \\
$\quad$ Community forest of La Petite Pierre & 28 & 19 & 2 & 7 & 0.071 & 0.714 & 0.286 \\
$\quad$ Donon & 15 & 13 & 0 & 2 & 0.000 & 0.866 & 0.134 \\
Riquewihr & 2 & 2 & 0 & 0 & - & - & - \\
$\quad$ Gérardmer & 8 & 8 & 0 & 0 & - & - & - \\
St Augustin (Allier) & 15 & 13 & 1 & 1 & 0.067 & 0.900 & 0.100 \\
Arc-en-Barois & 95 & 88 & 4 & 3 & 0.042 & 0.947 & 0.053 \\
Chambord & 222 & 62 & 111 & 49 & 0.491 & 0.529 & 0.471 \\
Corsica & 11 & 11 & 0 & 0 & 0.000 & 1.000 & 0.000 \\
\hline
\end{tabular}

Polymorphism was seen in all populations except Tyrrhenian red deer whose plasma contained only $T f A A$. Monomorphism of $T f A A$ has also been seen in another small sample series of Mediterranean red deer of the Iberian subspecies $(C e$ hispanicus) from Andalucia, Spain (unpublished data). Outgroup comparison using sika deer $(n=12)$ found only $T f B B$ in this closest relative of $C$ elaphus. Likewise, another Asiatic taxon, Bukhara red deer (Ce bactrianus) from Afghanistan and Kazakhstan ( 2 independently imported lines kept at Cologne Zoo) revealed only 
Tf $B B(n=6)$. Standard genetic distances according to Nei (table III, fig 2) cluster the mainland France populations together but Chambord deer are separated more distinctly at the $T f$ locus than Tyrrhenian deer from Corsica. This distinction of deer from the 5000 ha park around the Chateau de Chambord is also evident in elevated heterozygosity (table II) and $F_{\text {st }}$ value (table IV) which shows that intrapopulation variation adds a greater share to total variation of Chambord deer than was found in other herds. Deer from the Vosges and Arc-en-Barrois are separated by a smaller genetic distance at this single locus than Vosges deer in general from those in the community forest of La Petite Pierre within the Vosges mountains (table III, fig 2). This finding indicates spatial genetic subdivision of red deer from the Vosges (the only region where we have detailed information to delimit meaningful subpopulations, see below) which is obscured when combining samples from various localities.

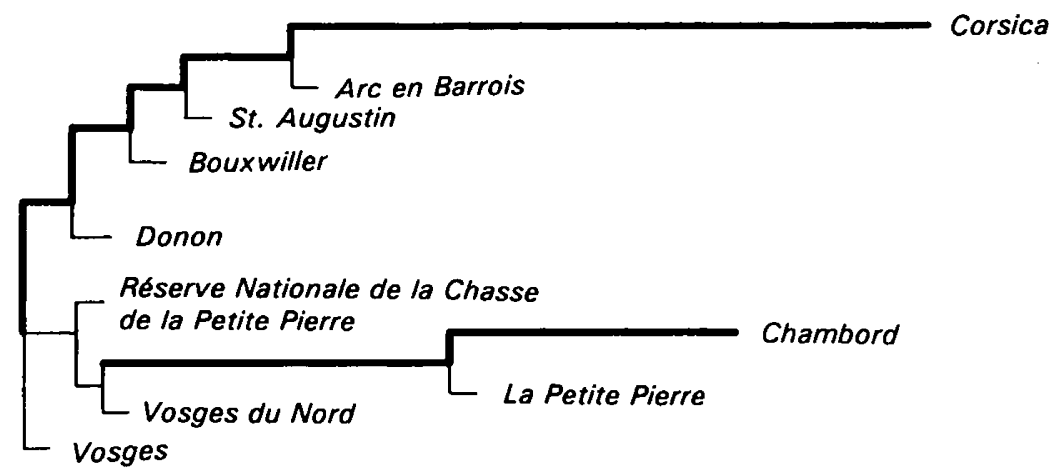

Fig 2. Unrooted tree on the basis of standard genetic distances at the $T f$ locus of reddeer populations, constructed with the neighbor-joining method (PHYLIP software, J Felsenstein). Thin lines denote branches with zero-lengths for graphical presentation. Deer from various localities from within the Vosges mountains have been included separately to show the effect of microgeographic differentiation upon clustering.

Deer from the Vosges mountains deviate highly significantly from HardyWeinberg equilibrium, being deficient in heterozygotes (chi-squared test with 2 classes, TfAA $+T f B B / T f A B ; p<0.001$ ). This deficiency in heterozygotes was confirmed during the sampling seasons 1989/1990, 1990/1991, and 1991/1992. Testing this disequilibrium for smaller subpopulations of Vosgian deer shows that it holds even within fairly small areas, eg, the Réserve Nationale de Chasse de la Petite Pierre (2600 ha), or the 1400 ha of the Forêt Domaniale de la Petite Pierre $(p<0.001$ and $p<0.001$, respectively). Partitioning the sampling area into arbitrary geographic sectors, ie using administrative boundaries between forest blocks to test whether the population was subdivided into geographic subpopulations (which would indicate a Wahlund effect) does not yield significant differences in allele frequencies between the demes thus defined. Allele frequencies did not differ between the year classes of deer born in 1989, 1990, and 1991 but we failed to acquire sufficient samples for testing possible temporal structuring of our frequencies in the 


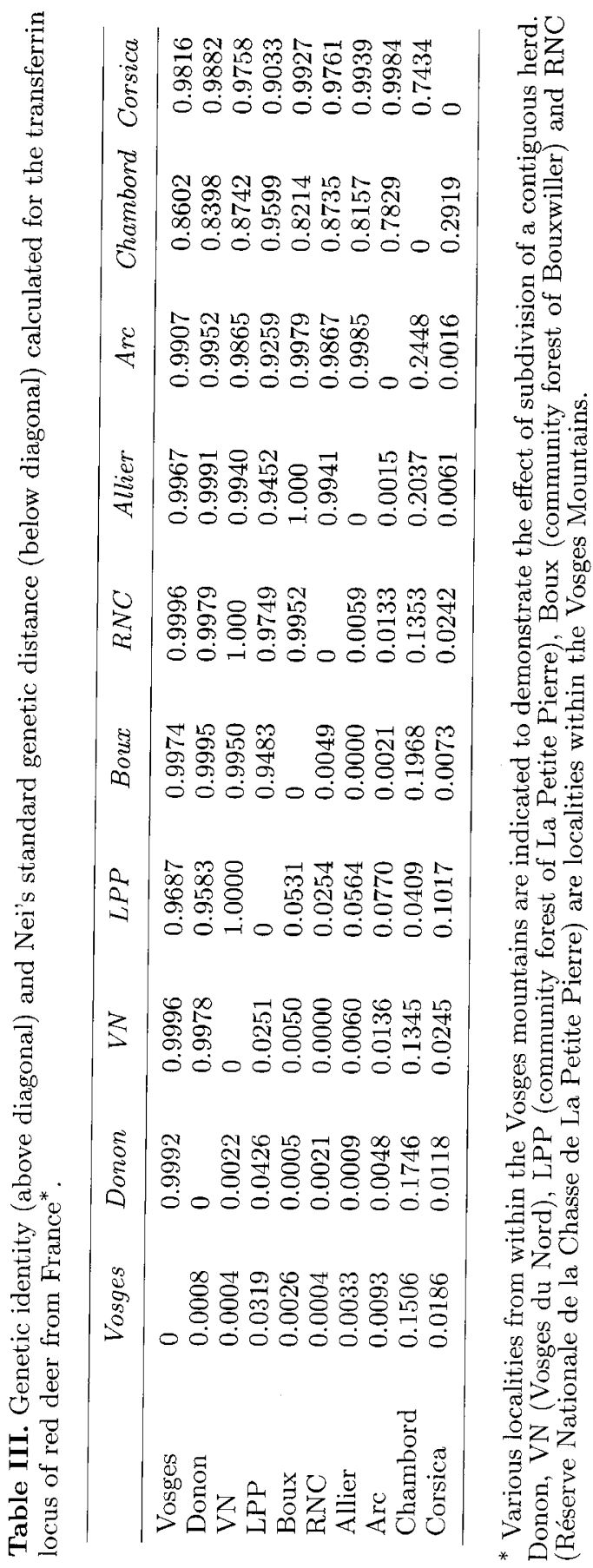




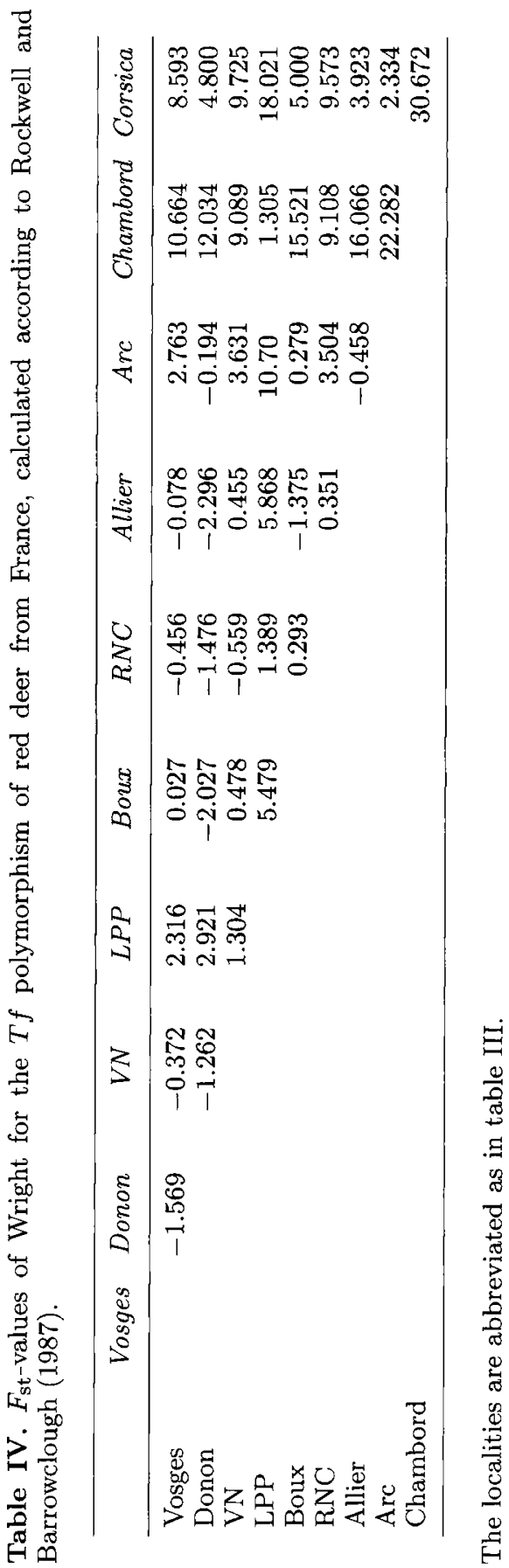


remaining 5 year classes represented in our study series $(1978,1984,1986,1987$, and 1988). There was no indication for a null allele in our samples; staining intensities of $T f$ bands did not differ markedly, and null-null homozygotes were not encountered. Inclusion of arbitrary frequencies of a null allele in our goodness-of-fit tests did not approach Hardy-Weinberg conditions but increased the chi-squared values.

Incorporation of information on deer sociobiology shows that adjacent matrilocal groups in Vosges du Nord (fig 3 ) differ in $T f$ allele frequency; data on hinds, calves and male offspring below 30 months of age were compared between the Bouxwiller deer $(n=41)$ and deer $(n=26)$ in the west of the reserve in the Forêt Domaniale de la Petite Pierre $(p<0.025)$. Behavioral study of 86 tagged, individually known females revealed marked philopatry of female deer, whereas $50 \%$ of males leave the area of La Petite Pierre after reaching 30 months of age. The average dispersal distance of females tagged as calves and shot after 30 months of age was $2.55 \mathrm{~km}$ (ranging from about 0.46 to $4.6 \mathrm{~km}, \mathrm{SD} 1.487$, variance 2.21), and $19.09 \mathrm{~km}$ for males (ranging from about 3.0 to $62.0 \mathrm{~km}$, SD 20.94, variance 438.74). Long-distance dispersers noted outside their birth region are confined to the male sex (fig 4a). Not a single female has been observed as crossing the demarcation line between both matrilocal groups indicated in figure 3, a phenomenon also evident from a map connecting tagging and hunting localities of individually known females (fig $4 \mathrm{~b}$ ). This is different to stags who do not recognize this boundary but wander freely. There is no obvious landscape demarcation which would hinder contact between both social groups. The minimum effective population size $\left(N_{e}\right.$ according to Nunney (1991)) within the contiguous habitat available for deer in that part of the Vosges mountains is calculated at approximately 209 animals, the actual population numbers at some 980 deer (a safe minimum number of 800 has been used for $N_{e}$ calculation). This $N_{e}$ considers effects of social and age structure on genetic drift but not of isolation by distance which depends on the one-way variance of geographic dispersal distances (Chepko-Sade and Shields, 1987; Materials and methods). Isolation by distance is not a factor to reduce $N_{e}$ either in Vosges du Nord or in Donon. Based on our empirical dispersal data, the neighborhood area that defines the area of randomly mating groups subject to the given dispersal system amounts to 183954 ha, which would contain 4599 individuals (2 575 breeders) in Vosges du Nord (where the mean spring population density is 2.5 animals and 1.4 breeders per $100 \mathrm{ha}$ ), and even 5519 individuals (3127 breeders) in the Donon area (with 3 specimens and 1.7 breeders per 100 ha in spring). The 85 th percentile $N_{e}$, which is the number of breeding adults within a circle whose radius is the greatest distance traveled by the closest $85 \%$ of dispersers, amounts to some 1807 breeders in Vosges du Nord or 2195 in the Donon area; the area of Vosgian habitat from which $85 \%$ of all parents of central individuals are derived is calculated as 129126 ha. Only populations inhabiting ranges larger than the mentioned areas would experience subdivision by distance isolation. In contrast, our herds number merely 444 breeders in Vosges du Nord, and 1728 breeders in Donon. Accordingly, there is no evidence whatsoever to suggest local inbreeding.

If the genetic analysis is confined to females and males younger than their age of dispersal, $T f$ genotype numbers in the Bouxwiller deme conform to HardyWeinberg equilibrium. This is different to the remainder of the reserve in which 

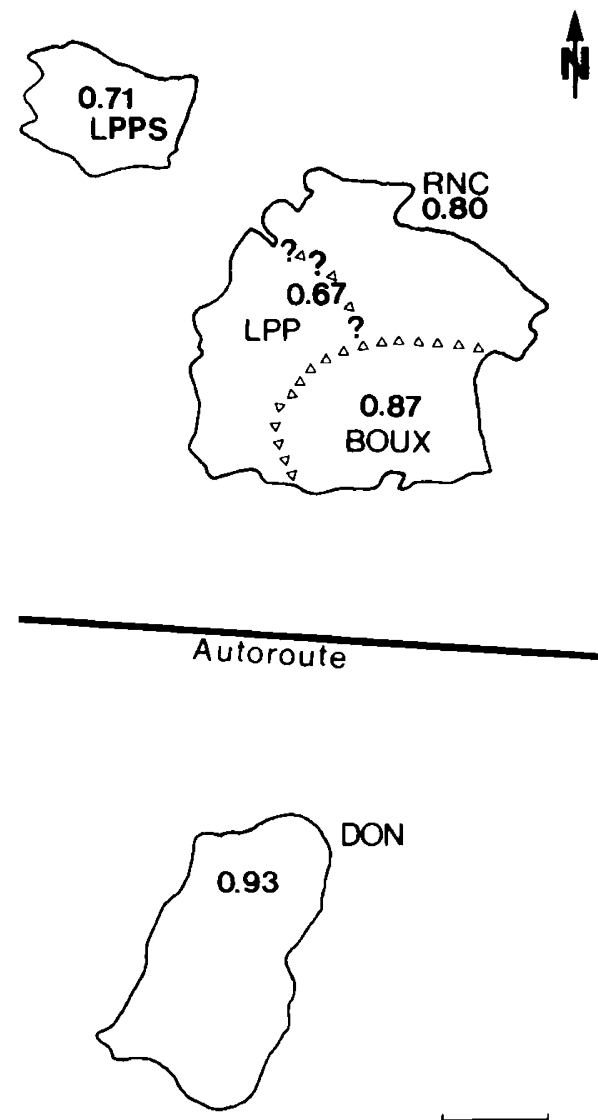

$2 \mathrm{~km}$

Fig 3. Geographic location of subpopulations of Vosgian red deer. Vosges du Nord comprises all territories north of the Paris-Strasbourg motorway. The numbers indicate the frequency of $T f a$ within the Réserve Nationale de la Chasse de la Petite Pierre; the separation between matrilocal groups is indicated by triangles. The west of the reserve is home to more than one deme although limits of additional groups are not sufficiently known. DON: Donon; RNC: Réserve Nationale de la Chasse de la Petite Pierre; BOUX: Bouxwiller deme; LPP: community forest of La Petite Pierre ; LPPS: Massif Domanial de la Petite Pierre Sud.

a highly significant disequilibrium remains. Genotype numbers in Donon may also suggest departure from equilibrium but the limited sample size prohibits tests.

At Chambord, where information concerning sociology is not available, subdivision of the area into arbitrary sectors using landscape markers or a coordinate grid did not reveal significant shifts in allele frequency between subpopulations thus defined. However, several of our samples were derived from live-captured animals, which had been caught in nets trapping small groups of deer (3-23 individuals) resting together during the day in tree thickets. Overall frequencies 

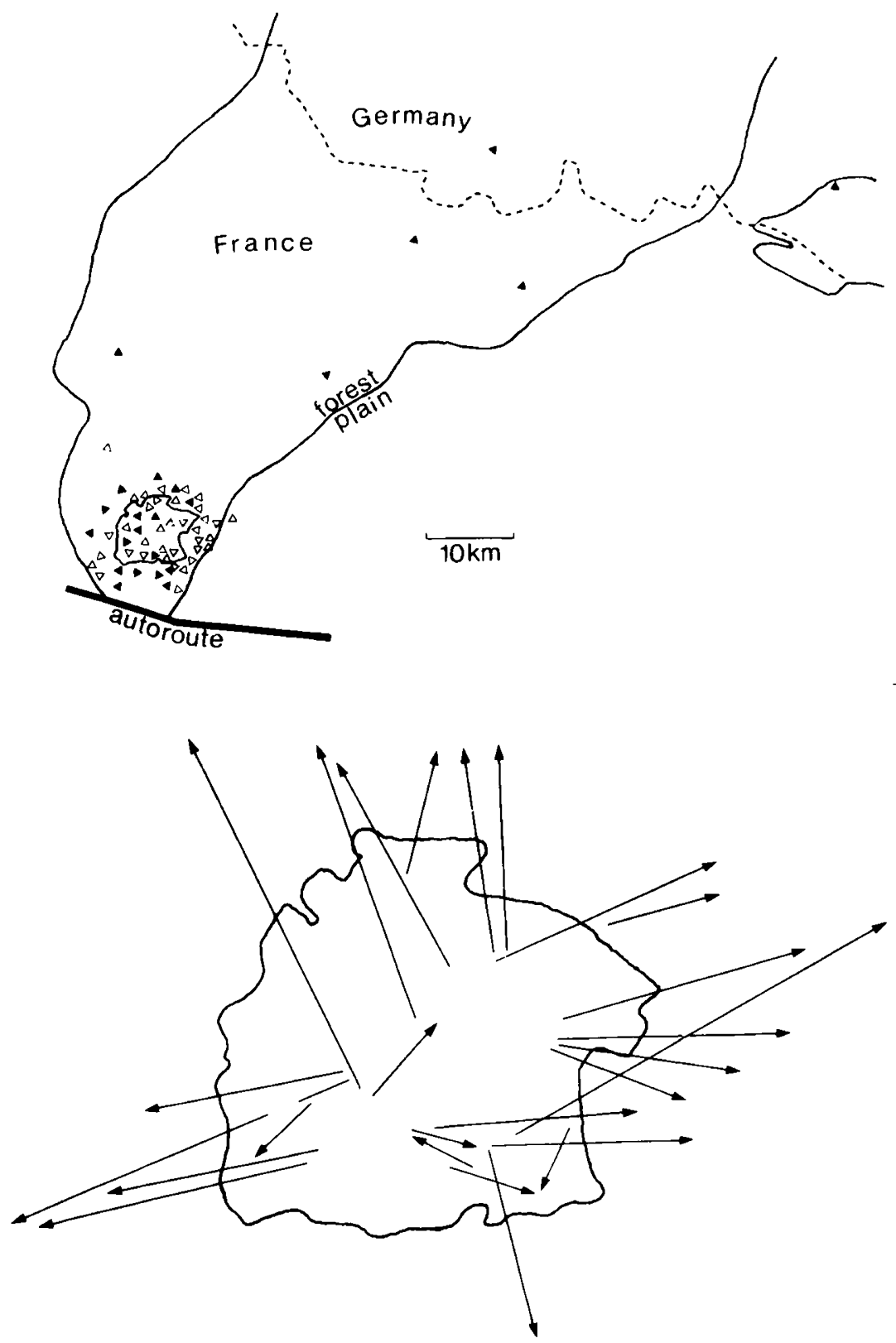

Fig 4. a) Dispersal distances of selected male (black triangles) and female (open triangles) red deer tagged as juveniles in the Réserve Nationale de la Chasse de la Petite Pierre. Longdistance dispersers are confined to the male sex. b) Distances between tagging localities and places of death of shot females within the Réserve Nationale de la Chasse de la Petite Pierre. This sample series also shows separation between both subpopulations as indicated in figure 3. 
of shot $(n=128 ; T f a=0.562 ; T f b=0.438)$ and net-captured deer $(n=94$; $T f a=0.484 ; T f b=0.516$ ) from Chambord did not differ significantly, but one out of 4 netting operations, which encircled sufficient deer for statistical comparison, trapped an aggregation of individuals whose $T f$ allele frequencies differed significantly from both the total number of deer trapped $\left(\chi^{2}=4.82\right.$, $p<0.05, d f=1)$ or shot $\left(\chi^{2}=6.49, p<0.025, d f=1\right)$ in Chambord during the seasons 1989-1991.

There is no significant correlation between one $T f$ allele (or heterozygosity at this locus) and the biometric traits that serve as criteria for selective trophy hunting (ANOVA I): body-weight or hind-foot length in hinds (of one, more than 2 or more than 5 yr of age) and spikers from La Petite Pierre or Chambord; antler length or antler diameter in spikers from La Petite Pierre or Chambord; and antler length, antler diameter, point number of trophy, length of eye beam or length of middle beam in stags ( $>7 \mathrm{yr}$ ) from Chambord. Calves of less than 3 months of age already displayed heterozygote deficiency when the frequency of the parental generation has been considered $(p<0.01)$, and there was no significant change of allele frequency between age classes indicating differential survival. Thus, any possible selective effect on $T f$ heterozygosity would have to affect the population between mating and 3 months of age in the following generation.

\section{DISCUSSION}

Heterozygote deficiency in transferrin polymorphism has previously been described from red deer from south Sweden (Gyllensten et al, 1980) and Austria (Mushövel, 1986) but its causes remained entirely speculative. Gyllensten et al (1980) whose sampling region covered at least $600 \mathrm{~km}^{2}$ in south Sweden suggested as an explanation either a Wahlund effect or selection against heterozygotes; Mushövel (1986) speculated about hunting selection against heterozygotes. Although not commented on by the author, this phenomenon appears in the data of Bergmann (1976) on deer from Harz and Solling, Germany. However, most sample series of red deer from several parts of west, north and central Europe conformed to HardyWeinberg expectations (McDougall and Lowe, 1968; Bergmann, 1976; Gyllensten et al, 1980, 1983; Mushövel, 1986; Herzog, 1988; Herzog et al, 1991). Herzog (1988) found a slight preponderance of homozygotes at the $T f$ locus in 4 out of 5 freeranging deer populations from Germany but no significant lack of $T f A B$. His small sample series from Harz $(n=16)$ behaved in good agreement with HardyWeinberg predictions, in contrast to Bergmann's (1976) genotype distributions which showed highly significant heterozygote deficiency for deer from this mountain chain $(n=82)$. Our data show that spatial shifts in frequency can occur at a very small geographic distance in areas without evident ecological subdivision. With a contiguous range accessible to an estimated minimum effective population size of 209 deer, there is no obvious external force for drift or inbreeding. This suggests caution when investigating this polymorphism without good knowledge of microgeographic origin of samples, and to apply a critical population concept prior to any population genetic analysis.

Sociology of deer is the most plausible explanation in our herd for the spatial frequency differences observed between the western and eastern portion of a reserve 
of 2600 ha. A third matrilocal group is thought to occupy the northern sector of the reserve of La Petite Pierre, but we were unable to map its core area or limits, and we cannot decide if the heterozygote deficiency in the Forêt Domaniale de la Petite Pierre (1 $400 \mathrm{ha})$ is also due to a Wahlund effect. If core areas between matrilineal groups overlap in such a complex pattern as described by Clutton-Brock et al (1980) for red deer living in open moorland in Scotland (on the basis of behavioral observation), our sample series from this small territory may well be stratified as well. The analysis of 7 allozyme polymorphisms did not indicate Hardy-Weinberg disequilibria in these deer (Hartl et al, 1990, 1991), and small-scale shifts in allele frequencies (Hartl et al, unpublished data) were not apparent, with the exception of the 2 alleles of $M e-2$. Thus, if mild genetic drift explains $T f$ heterozygote deficiency, an additional hypothesis is required to explain why this would affect different loci to different extents. Interestingly, we did not encounter any correlation between a $T f$ allele and any of the tested phenotypic traits, including those which are important criteria of hunting selection, the dominant cause of mortality in the population. The $M e$ - 2 allele did not correlate with phenotypic traits either (Hartl et al, unpublished data). In contrast, the allozyme polymorphisms $M e-1, I d h-2, A c p-$ 1 and Acp-2 revealed associations of alleles with biometric parameters (Hartl et al, 1991), including important factors of differential mortality (via trophy hunting). Social structures may be too transient to affect polymorphisms which are influenced by selection but could lead to mild and possibly transient differentiation in neutral systems. There is little hard evidence for factors selecting against $T f$ heterozygosity in cervids, the obvious alternative parameter to lead to heterozygote deficiency. In the red deer of Rhum (Scotland), neither of the $2 T f$ alleles significantly correlated with juvenile mortality but incorporation of $T f$ data into a correlation involving allozyme loci showed that heterozygous deer survived better than homozygotes (Pemberton et al, 1988). In Scandinavian reindeer, the most common $T f$ allele was positively associated with body weight in male calves but not in yearlings, while the second most common allele was associated with body mass among male yearlings but not among calves, a phenomenon explained by balancing selection (Roed, 1987). Zhurkevich and Fomicheva (in Gyllensten et al, 1980) described selection against reindeer heterozygous for $T f$; differences for viability were found under harsh conditions and for susceptibility to epidemic bacterial infections between carriers of different $T f$ genotypes. There is no knowledge about the mechanisms involved but most of the possible physiological mechanisms which have been reported to influence $T f$ polymorphism of vertebrates focus on an unspecified immunological function which has been demonstrated for ovo- and lactotransferrin but less for serum transferrin (Frelinger, 1972). Transferrin has been identified in seminal fluid (Lane, 1976) although its function in sperm appears to be unknown. Numerous studies found that pairings between domestic cattle with certain $T f$ combinations resulted in biased $T f$-genotypes among offspring. However, different investigators arrived at different conclusions in various populations (Buschmann and Schmid, 1968), and there are no data on cervids.

All calculated parameters of descriptive genetics $\left(H, F_{\mathrm{st}}\right.$, standard genetic distance) place the deer from Chambord apart from the other large herds in mainland France. Mushövel (1986) found enclosed deer from Nordhessen to be highly distinct at the $T f$ locus from adjacent free-ranging deer from which the 
semi-captive population had descended, including a much higher heterozygosity when compared to their free-living relatives, and similar trends were observed in 2 additional enclosures. Deer at Chambord occupy a fenced habitat of 5000 ha which has been isolated for centuries although we are not aware of the possibly noteworthy number of specimens from various origins that have been imported for hunting purposes. Considering the dispersal behavior of the red deer that we observed in an unrestricted population, a natural population of the size living at Chambord would extend to a considerably larger area, and mix with the deer living there. According to some generalizing models of conservation genetics which are meant to preserve polymorphism in relict stocks (Schreiber, 1991), our results on $T f$ variability at Chambord were not to be expected.

We conclude that generalizing models predicting loss of genetic variability in isolated populations and derived management strategies are useful if they are tailored to the particular needs of the population under concern. The selection of founder individuals for stock translocation is one practical aspect in this regard. Many reintroductions in France use animals from Chambord although this population differs in its genetic structure from the investigated autochthonous herds. Since reintroduction projects frequently comprise a few deer only, the genetic microstructure of populations easily determines the degree of genetic drift implied. Few autochthonous populations of red deer remain in Central Europe to study natural population patterns. Although small-scale structuring appears to be less pronounced in Vosgian red deer than in the white-tailed deer studied by Scribner (1994), and we have no evidence of temporal structuring of allele frequencies within a few successive years as has been described from Odocoileus (Scribner, 1993), the population structure in red deer is sufficiently complex to require much more empirical work before strategies for the conservation of allelic diversity can be formulated. The grossly different social systems of Vosgian red deer to the sociologically best studied population of the species in Scottish moorlands (Clutton-Brock et al, 1982) are almost certainly reflected in different ratios between numerical and effective population sizes. The effective population size reported here may be more typical of red deer inhabiting broad-leaved or mixed forests which is the species, favorite habitat throughout Europe.

\section{ACKNOWLEDGMENTS}

We gratefully acknowledge the support with serum samples by: F Forget and JJ Courthial (Chambord); JL Hamann, A Magar, JL Wilhelm and H Holveck (La Petite Pierre); $\mathrm{J}$ Barrat of the Laboratoire d'étude sur la rage et la pathologie des animaux sauvages (Malzeville, France) ; R Kock (Whipsnade Wild Animal Park, UK); and L Kolter and W Zimmermann (Kölner Zoo, Germany, sampled reference sera from Asiatic deer). M Theriez and A Brelurut of the Institut National de la Recherche Agronomique (Theix, France) supplied samples of pedigree deer. The Office National des Forêts (Saverne, France) and the Parc Naturel Régional de Corse supported our work. 


\section{REFERENCES}

Bergmann F (1976) Beiträge zur Kenntnis der Infrastrukturen beim Rotwild. II. Erste Versuche zur Klärung der genetischen Struktur von Rotwildpopulationen and Hand von Serum-Protein-Polymorphismen. Jagwiss 22, 28-35

Buschmann H, Schmid DO (1968) Serumgruppen bei Tieren. Parey-Verlag, Berlin Chepko-Sade BD, Shields WM (1987) The effects of dispersal and social structure on effective population size. In: Mammalian Dispersal Patterns. The Effect of Social Structure on Population Genetics (BD Chepko-Sade, HZ Tang, eds) Chicago University Press, Chicago, 287-321

Clutton-Brock TH, Albon SD, Guiness FE (1980) Competition between female relatives in a matrilocal mammal. Nature (Lond) 300, 178-180

Clutton-Brock TH, Guiness FE, Albon SD (1982) Red Deer. Behaviour and Ecology of Two Sexes. Edinburgh University Press, Edinburgh

Dratch PA, Pemberton JM (1992) Application of biochemical genetics to deer management: what the gels tell. In: The Biology of Deer (RD Brown, ed) SpringerVerlag, New York, 367-383

Chesser RK, Smith MH, Johns PE, Manlove MN, Straney DO, Baccus R (1982) Spatial, temporal, and age-dependent heterozygosity of beta-hemoglobin in whitetailed deer. $J$ Wildl Manage 46, 983-990

Frelinger JA (1972) The maintenance of transferrin polymorphism in pigeons. Proc Natl Acad Sci USA 69, 326-329

Gyllensten U, Reuterwall C, Ryman N, Stahl G (1980) Geographical variation of transferrin allele frequencies in three deer species from Scandinavia. Hereditas 92, 237-241

Gyllensten U, Ryman N, Reuterwall C, Dratch P (1983) Genetic differentiation in four European subspecies of red deer (Cervus elpahus L). Heredity 51, 561-580

Harrington R (1985) Evolution and distribution of the cervidae. $R$ Soc NZ Bull 22, 3-11

Hartl GB, Lang G, Klein F, Willing R (1991) Relationships between allozymes, heterozygosity and morphological characters in red deer (Cervus elaphus), and the influence of selective hunting on allele frequency distributions. Heredity 66, 343-350 Hartl GB, Reimoser F (1988) Biochemical variation in roe deer (Capreolus capreolus L): are r-strategists among deer genetically less variable than k-strategists? Heredity $60,221-227$

Hartl GB, Willing R, Lang G, Klein F, Köller J (1990) Genetic variability and differentiation in red deer (Cervus elaphus L) of Central Europe. Genet Sel Evol $22,289-306$

Herzog S (1988) Cytogenetische und biochemisch-genetische Untersuchungen and Hirschen der Gattung Cervus. Göttingen Res Notes For Genet 10, 1-139

Herzog S, Mushövel C, Hattemer HH, Herzog A (1991) Transferrin polymorphism and genetic differentiation in Cervus elaphus L (European red deer) populations. Heredity $67,231-239$

Jung P (1990) L'implantation du cerf vosgien: données historiques. La chasse en Alsace et en Lorraine, May 1990, 14-16 
Klein F, Hartl GB, Schreiber A, Lang G (1992) The biological management of red deer (Cervus elaphus L). In: Ongulés/Ungulates 91 (F Spitz, G Janeau, G Gonzalez, S Aulagnier, eds) SFEPM, IRGM, Paris, Toulouse, 113-115

Kurt F (1991) Das Reh in der Kulturlandschaft. Sozialverhalten und Ökologie eines Anpassers. Paul Parey, Hamburg

Lane RS (1976) Transferrin. In: Structure and Function of Plasma Proteins (AC Allison, ed) vol 2, Plenum Press, New York

Lang G (1987) Gestion des populations de Cervidés. Réflexions sur des problèmes de polymorphisme génétique. PhD Thesis, University of Strasbourg

Manlove MN, Smith MH, Hillestad HO, Fuller SE, Johns PE, Straney DO (1976) Genetic subdivision in a herd of white-tailed deer as demonstrated by spatial shifts in gene frequencies. Proc 30th Ann Conf SE Game Fish Comm 30, 487-492

McDougall EI, Lowe VPW (1968) Transferrin polymorphism and serum proteins of some British deer. J Zool 155, 131-140

Mushövel C (1986). Serumtransferrine von Rotwild (Cervus elaphus L) und Rehwild (Capreolus capreolus L). PhD Thesis, University of Giessen

Nelson ME, Mech LD (1987) Demes within a northeastern Minnesota deer population. In: Mammalian Dispersal Patterns the Effects of Social Structure on Population Genetics (BD Chepko-Sade, H Tang, eds) Chicago University Press, Chicago, $27-40$

Nunney L (1991) The influence of age structure and fecundity on effective population size. Proc $R$ Soc $B$ 246, 71-76

Pemberton JM, Albon SD, Guiness FE, Clutton-Brock TH, Berry RJ (1988) Genetic variation and juvenile survival in red deer. Evolution 42, 921-934

Pemberton JM, Albon SD, Guiness FE, Clutton-Brock TH, Dover GA (1992) Behavioural estimates of male mating success tested by DNA fingerprinting in a polygynous mammal. Behav Ecol, 1, 66-75

Rockwell RF, Barrowclough GF (1987) Gene flow and the genetic structure of populations. In: Avian genetics. A Population and Ecological Approach (F Cooke, PA Buckley, eds) Academic Press, London, 223-255

Roed KH (1987) Transferrin variation and body size in reindeer, Rangifer tarandus L. Hereditas 106, 67-71

Ryman N, Beckman G, Bruun-Petersen G, Reuterwall C (1977) Variability of red cell enzymes and genetic implications of management policies in Scandinavian moose (Alces alces). Hereditas 85, 157-162

Scribner KT (1993) Conservation genetics of managed ungulate populations. Acta Theriologica 38, Suppl 2, 89-101

Schreiber A (1991) Molekulare Individualität und Naturschutz. Populationsgenetische Beiträge zur Erhaltung bedrohter Arten. PhD Thesis, University of Heidelberg. Schreiber A, Klein F, Lang G (1992) Deficiency of heterozygotes at the transferrin locus in an autochthonous population of Central European red deer. In: Ongulés/Ungulates 91 (F Spitz, G Janeau, G Gonzalez, S Aulagnier, eds) SFEPM, IRGM, Paris, 117-222

Smith MH, Baccus R, Hillestad HO, Manlove MN (1984) Population genetics. In: White-Tailed Deer: Ecology and Management (LK Halls, ed), Stackpole Books, Harrisburg 